\title{
Neurotensin Activates GABAergic Interneurons in the Prefrontal Cortex
}

\author{
Kimberly A. Petrie, ${ }^{1}$ Dennis Schmidt, ${ }^{1}$ Michael Bubser, ${ }^{1}$ Jim Fadel, ${ }^{1}$ Robert E. Carraway, ${ }^{2}$ and Ariel Y. Deutch ${ }^{1}$ \\ ${ }^{1}$ Departments of Pharmacology and Psychiatry, Vanderbilt University Medical Center, Nashville, Tennessee 37212, and ${ }^{2}$ Department of Physiology, \\ University of Massachusetts Medical Center, Worcester, Massachusetts 01655
}

Converging data suggest a dysfunction of prefrontal cortical GABAergic interneurons in schizophrenia. Morphological and physiological studies indicate that cortical GABA cells are modulated by a variety of afferents. The peptide transmitter neurotensin may be one such modulator of interneurons. In the rat prefrontal cortex (PFC), neurotensin is exclusively localized to dopamine axons and has been suggested to be decreased in schizophrenia. However, the effects of neurotensin on cortical interneurons are poorly understood. We used in vivo microdialysis in freely moving rats to assess whether neurotensin regulates PFC GABAergic interneurons. Intra-PFC administration of neurotensin concentration-dependently increased extracellular GABA levels; this effect was impulse dependent, being blocked by treatment with tetrodotoxin. The ability of neurotensin to increase GABA levels in the PFC was also blocked by pretreatment with 2-[1-(7-chloro-4-quinolinyl)-5-(2,6-dimethoxyphenyl)pyrazole-3-yl)carbonylamino]tricyclo(3.3.1.1. $\left.{ }^{3.7}\right)$ decan-2-carboxylic acid (SR48692), a high-affinity neurotensin receptor 1 (NTR1) antagonist. This finding is consistent with our observation that NTR1 was localized to GABAergic interneurons in the PFC, particularly parvalbumin-containing interneurons. Because neurotensin is exclusively localized to dopamine axons in the PFC, we also determined whether neurotensin plays a role in the ability of dopamine agonists to increase extracellular GABA levels. We found that $\mathrm{D}_{2}$ agonist-elicited increases in PFC GABA levels were blocked by pretreatment with SR48692, consistent with data indicating that $\mathrm{D}_{2}$ autoreceptor agonists increase neurotensin release from dopamine-neurotensin axons in the PFC. These findings suggest that neurotensin plays an important role in regulating prefrontal cortical interneurons and that it may be useful to consider neurotensin agonists as an adjunct in the treatment of schizophrenia.

Key words: dopamine; GABA; interneuron; neurotensin; prefrontal cortex; schizophrenia

\section{Introduction}

Alterations in the function of the prefrontal cortex (PFC) are thought to underlie the cognitive deficits and negative symptoms of schizophrenia. Neuropathological studies indicate a dysfunction of cortical GABAergic neurons in schizophrenia. Among the changes observed in postmortem studies of schizophrenia is a decrease in levels of the mRNA encoding $\mathrm{GAD}_{67}$, the GABA synthetic enzyme (Akbarian et al., 1995; Volk et al., 2000; Volk and Lewis, 2002; Hashimoto et al., 2003). Other studies have uncovered a corresponding upregulation of prefrontal cortical $\mathrm{GABA}_{\mathrm{A}}$ receptor mRNA and binding (Benes et al., 1996; Ohnuma et al., 1999; Volk and Lewis, 2002) and reduced expression of the GABA transporter GAT-1 (Ohnuma et al., 1999; Pierri et al., 1999; Volk et al., 2001), which may be compensatory responses to decreased GABAergic tone. In addition, changes in the expression of calcium-binding proteins that are localized to different popula-

\footnotetext{
Received Aug. 31, 2004; revised Dec. 10, 2004; accepted Jan. 3, 2005

This work was supported by a National Research Service Award to K.A.P. (F32 MH 12972), a National Alliance for Research on Schizophrenia and Depression Young Investigator Award (J.F.), National Institute of Mental Health (NIMH) Grants MH 45124 and MH 57995 (A.Y.D.), and the National Parkinson Foundation Center of Excellence at Vanderbilt University. We appreciate the assistance of Bryan Roth of the NIMH Psychoactive Drug Screening Program and Sanofi Recherche for providing SR48692 and thank Tamara Geraci for assistance with figure preparation.

Correspondence should be addressed to Ariel Y. Deutch, Psychiatric Hospital at Vanderbilt, Suite 313, 1601 23rd Avenue South, Nashville, TN 37212. E-mail: ariel.deutch@vanderbilt.edu.

D01:10.1523/JNEUROSCI.3579-04.2005

Copyright $\odot 2005$ Society for Neuroscience $\quad$ 0270-6474/05/251629-08\$15.00/0
}

tions of cortical interneurons have been reported (Daviss and Lewis, 1995; Beasley and Reynolds, 1997; Reynolds and Beasley, 2001; Reynolds et al., 2002).

Because of the central role that interneurons play in cortical function and the posited dysfunction of GABAergic cells in schizophrenia, it is important to understand the regulatory mechanisms that govern the activity of GABAergic interneurons. In the rodent, the peptide transmitter neurotensin (NT) is found in a subpopulation of dopamine neurons that project from the ventral tegmental area (VTA) to the PFC (Hokfelt et al., 1984; Seroogy et al., 1987; Studler et al., 1988). There are no neurotensin-containing cell bodies in the rat PFC, and the only source of neurotensin in the PFC is in axons derived from VTA neurons that also contain tyrosine hydroxylase, the dopamine synthetic enzyme (Studler et al., 1988; Febvret et al., 1991). Thus, neurotensin in the rat PFC is exclusively localized to dopamine axons. Because an estimated 39\% of synaptic contacts in the PFC that are made by dopamine terminals are with GABA-containing dendrites (Sesack et al., 1995a), neurotensin may be a critical regulator of GABAergic function.

Audinat et al. (1989) reported that neurotensin increases bicuculline-sensitive $\left(\mathrm{GABA}_{\mathrm{A}}\right.$-mediated) IPSPs in PFC pyramidal cells. In addition, we found recently that systemic administration of the neurotensin agonist PD149163 increases Fos expression in prefrontal cortical GABA interneurons (Petrie et al., 
2004). These studies suggest that neurotensin modulates the activity of GABAergic interneurons, but direct studies are lacking.

We explored the hypothesis that neurotensin activates prefrontal cortical GABA interneurons. Using fluorescent immunohistochemistry, we determined whether the high-affinity neurotensin receptor NTR1 is localized to GABAergic interneurons. We then used in vivo microdialysis to assess the effects of intracortical neurotensin administration on extracellular GABA levels. Finally, because neurotensin is colocalized with dopamine in the rat PFC, we determined whether cortical neurotensin release accounts for the paradoxical increase in extracellular GABA levels observed after administration of dopamine $\mathrm{D}_{2}$-like agonists (Grobin and Deutch, 1998).

\section{Materials and Methods}

Subjects. Adult male Sprague Dawley rats weighing 275-345 g (Harlan, Birmingham, AL) were group housed on a $12 \mathrm{~h}$ light/dark cycle with lights on at 6:00 A.M. Food and water were available ad libitum. All studies were performed in accordance with the National Institutes of Health Guide for Care and Use of Laboratory Animals and under the oversight of the Vanderbilt University Animal Care and Use Committee.

NTR1 antibody generation. Rabbits were immunized with keyhole limpit hemocyanin-conjugated synthetic peptides corresponding to the $\mathrm{N}$-terminal region (residues $1-18,5-21$, and 50-69) of NTR1. The antibodies generated were used to probe immunoblots of protein extracts from rat cortex, hypothalamus, liver, and lung. Tissues were homogenized, and $\mathrm{P} 2$ pellets were obtained as described previously (Carraway et al., 1993). Proteins were separated by SDS-PAGE on 10\% gels. Equal amounts of protein were transferred to polyvinylidene difluoride membranes, and antibody specificity was assessed using immunoblots, as described previously (Carraway et al., 2003).

Immunohistochemistry. Rats were perfused with PBS followed by cold $4 \%$ paraformaldehyde in $0.1 \mathrm{~m}$ phosphate buffer, $\mathrm{pH}$ 7.4. Coronal $40 \mu \mathrm{m}$ thick sections were cut on a freezing microtome. To determine whether NTR1 is localized to specific types of GABAergic interneurons, a dual immunofluorescence protocol (Fadel and Deutch, 2002) was used to reveal NTR1-like immunoreactivity and one of three calcium-binding proteins that define functionally distinct sets of interneurons (Kawaguchi and Kubota, 1993). Parvalbumin (PV)-, calbindin (CB)-, and calretinin (CR)-containing cells in the PFC together account for the vast majority of interneurons (Gabbott et al., 1997). Control procedures in immunohistochemistry experiments included preadsorption of the NTR1 antibody with the peptide fragment against which the antibody had been generated $(10 \mu \mathrm{g} / \mathrm{ml})$ and omission of the primary antibody. Sections were incubated in a mixture of primary antibodies directed against NTR1 (1:4000) and one of three calcium-binding proteins, including mouse anti-parvalbumin (1:1500; Sigma, St. Louis, MO), mouse anti-calbindin (1:2000; Sigma), and goat anti-calretinin (1:2500; Chemicon, Temecula, CA). Secondary antibodies were cyanine 3 (Cy3)conjugated donkey anti-rabbit IgG (1:1500; Jackson ImmunoResearch Laboratories, West Grove, PA) and Cy2-conjugated donkey anti-mouse or anti-goat IgG (1:1250; Jackson ImmunoResearch Laboratories).

Sections were examined under epifluorescent illumination to determine the percentage of NTR1-like immunoreactive (-li) neurons that also were immunoreactive for one of the three calcium binding proteins. In each animal, at least 100 PV-, 100 CB-, and 50 CR-li neurons were counted in a "column" of the prelimbic cortex running from the white matter to the pial surface; the percentage of the calcium-binding protein expressing cells that were also immunoreactive for NTR1 was determined.

Surgical procedure. Animals were anesthetized and placed into a stereotaxic frame. A burr hole was drilled over the target area [anteroposterior, +2.8; lateral, +2.1; dorsoventral, -2.3 (Paxinos and Watson, 1986)], and a guide cannula (Bioanalytical Systems, West Lafayette, IN) was inserted into the brain at a $17^{\circ}$ angle, just medial and parallel to the white matter of the forceps minor. The guide cannula was secured to the skull with dental acrylic, and ampicillin $(150 \mathrm{mg} / \mathrm{kg}$, s.c.; Henry Schein, Melville, NY) was administered prophylactically.

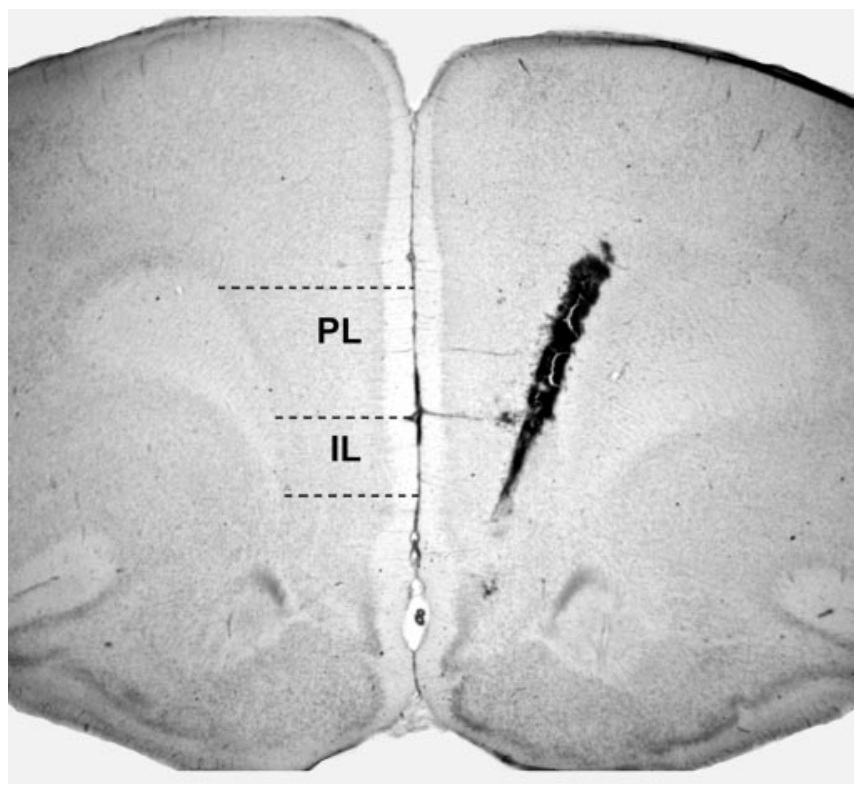

Figure 1. Typical localization of the microdialysis probe in the PFC. In this toluidine bluestained section, the exchange portion of the probe can be seen in the deep layers of the prelimbic (PL) and infralimbic (IL) PFC.

Microdialysis. Four to six days after surgery, the animals were transferred to dialysis chambers. A microdialysis probe $(260 \mu \mathrm{m}$ outer diameter, with a $3.0 \mathrm{~mm}$ exchange length; Bioanalytical Systems) was inserted through the guide cannula. The probe was perfused overnight at a flow rate of $0.2 \mu \mathrm{l} / \mathrm{min}$ with artificial CSF (ACSF) containing (in mM): 1.25 $\mathrm{CaCl}_{2}, 0.83 \mathrm{MgCl}_{2}, 120 \mathrm{NaCl}, 20 \mathrm{NaHCO}_{3}, 2.2 \mathrm{KCl}, 0.5 \mathrm{Na}_{2} \mathrm{SO}_{4}, 0.5$ $\mathrm{KH}_{2} \mathrm{PO}_{4}, 4.9 \mathrm{D}$-glucose, and 0.2 ascorbic acid, $\mathrm{pH}=6.9 \pm 0.1$. The next morning, the flow rate was increased to $2.0 \mu \mathrm{l} / \mathrm{min}$. After a $90 \mathrm{~min}$ equilibration period, four baseline perfusate fractions were collected at $20 \mathrm{~min}$ intervals; basal extracellular GABA levels, uncorrected for probe recovery, averaged $61.3 \pm 3.4 \mathrm{fmol} / \mu \mathrm{l}$.

Neurotensin or quinpirole was administered through the dialysis probe during the next $20 \mathrm{~min}$ fraction; control animals received the ACSF vehicle. In some cases, animals were pretreated with the NTR1 antagonist 2-[1-(7-chloro-4-quinolinyl)-5-(2,6-dimethoxyphenyl)pyrazole-3-yl) carbonylamino] tricyclo(3.3.1.1. ${ }^{3.7}$ )decan-2-carboxylic acid (SR48692) or vehicle (DMSO at a final concentration of $0.002 \%$ in ACSF) administered through the dialysis probe in the fraction before, during, and after administration of agonist. To control for variability in flow rate associated with syringe switching, the syringes containing ACSF were always changed in parallel for drug- and vehicle control-treated animals. Dialysates were collected for an additional $120-160 \mathrm{~min}$ and stored at $-80^{\circ} \mathrm{C}$ until analyzed for amino acid levels by HPLC.

At the end of the dialysis session, the animals were anesthetized and perfused with $4 \%$ paraformaldehyde in $0.1 \mathrm{~m}$ phosphate buffer. The brains were removed, and serial $100 \mu \mathrm{m}$ coronal sections through the PFC were cut and stained with toluidine blue. A person unaware of the treatment condition of the animals evaluated the sections for acceptable probe placement, which met the following criteria: the exchange portion of the probe was in the deep layers of the prelimbic and infralimbic PFC and did not cross the midline, penetrate the white matter, or enter the anterior olfactory nucleus (Fig. 1).

Drug treatments. We determined the effects of intra-PFC delivery of neurotensin (100 nM and $1 \mu \mathrm{m}$; Sigma) on extracellular GABA levels in the PFC and determined whether NT-evoked changes in extracellular GABA levels were modified by pretreatment with the NTR1 antagonist SR48692 (100 or 500 nм; Sanofi Recherche, Toulouse, France) or its vehicle (DMSO at a final concentration of $0.002 \%$ in ACSF). We also determined whether changes in extracellular GABA levels required depolarization of GABA neurons by pretreating with the sodium channel blocker tetrodotoxin (TTX; $1 \mu \mathrm{M}$; Sigma).

In an experiment aimed at assessing the role of neurotensin in $\mathrm{D}_{2}$ 


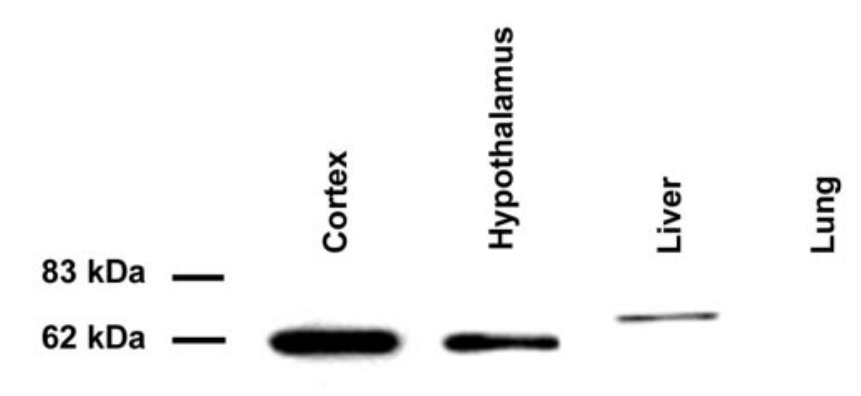

$47.5 \mathrm{kDa}-$

\section{$32.5 \mathrm{kDa}-\longrightarrow$}

Figure 2. Immunoblot showing expression of NTR1 in rat brain and peripheral sites. Consistent with the known distribution of NTR1, a $60 \mathrm{kDa}$ band representing glycosylated NTR1 is visible in protein samples from rat cortex, hypothalamus, and liver but not lung. The lowermolecular-weight band appears to be an NTR1 fragment.

agonist-evoked increases in extracellular GABA levels in the PFC, animals received either vehicle or quinpirole (100 $\mu \mathrm{m}$; Sigma) through the dialysis probe; the active drug concentration was based on previous data from our laboratory indicating that this concentration of the $\mathrm{D}_{2}$ agonist reliably increases prefrontal cortical extracellular GABA levels (Grobin and Deutch, 1998). Some quinpirole-infused animals were pretreated with the NTR1 antagonist SR48692.

SR48692 binding affinities for dopamine receptors. To determine whether SR48692 had any affinity for dopamine receptors, the NTR1 antagonists was screened against human $\mathrm{D}_{1}, \mathrm{D}_{2}$ long $, \mathrm{D}_{3}, \mathrm{D}_{4}$, and $\mathrm{D}_{5}$ receptors by the National Institute of Mental Health Psychoactive Drug Screening Program, as described previously (Shapiro et al., 2003) (a full description of assay conditions can be found at http://kidb.cwru.edu/nimh/binding.php).

HPLC. The levels of amino acids in the dialysates were determined using reverse-phase HPLC with electrochemical and fluorescent detection. GABA was added to dialysis samples as an internal standard. Samples were derivitized using $o$-pthalaldehyde and loaded into an autosampler for injection onto a $1.5 \mu \mathrm{m}$ C18 column (Alltech Associates, Deerfield, IL). The mobile phase was $100 \mathrm{~mm}$ sodium phosphate buffer containing $10 \%$ methanol, $\mathrm{pH} 3.70$, and the flow rate was set at 1.2 $\mathrm{ml} / \mathrm{min}$ with the column temperature maintained at $40^{\circ} \mathrm{C}$. The glutamate and GABA derivitization products were detected with an RF-10Axl fluorescence detector (Shimadzu, Kyoto, Japan) and an electrochemical detector (ESA, Chelmford, MA) placed in series.

Statistical analysis. Mean baseline levels of GABA and glutamate were determined by averaging the amino acid level in each of the four baseline fractions. If any baseline sample from an animal varied by $>30 \%$ of the mean, it was eliminated; data from animals with less than three baseline samples were not included in the analysis. Data were analyzed using two-factor (time $\times$ treatment) ANOVA with repeated measures on the time factor. If a significant interaction was detected, Bonferroni post hoc tests were used to determine the source of the variation.

\section{Results}

\section{Expression of NTR1 in the PFC}

Extracts of rat brain membranes probed with the NTR1 antibody showed a major band at $60 \mathrm{kDa}$ (Fig. 2), with a minor band present at $\sim 33 \mathrm{kDa}$. The larger band represents glycosylated NTR1, whereas the $33 \mathrm{kDa}$ band appears to be a neurotensin receptor fragment (Boudin et al., 1995). When large amounts of protein from liver and lung extracts were loaded onto the gel, a faint higher-mass band could be seen in liver but not lung samples, consistent with the known distribution of NTR1 (Mendez et al., 1997). Identical blots that were developed with the NTR1 antibody preadsorbed with the peptide antigen showed no specific staining (data not shown).

NTR1-like immunoreactive neurons were widely distributed in the PFC, including the infralimbic, prelimbic, and shoulder cortices. There was a sharp decrease in the density of NTR1-li neurons in the more lateral motor and somatosensory cortex. NTR1-li neurons in the PFC were mainly encountered in the deep layers, with fewer NTR1-li neurons present in the superficial layers. NTR1-like immunoreactivity appeared to be concentrated at the perimeter of cortical cells, suggesting that the receptor is predominantly membrane associated (Fig. 3). NTR1 immunoreactivity was not observed in sections incubated in antibody preadsorbed with NTR1 peptide nor in sections in which the primary antibody was omitted (data not shown).

Most prefrontal cortical NTR1-li neurons had a characteristic pyramidal cell morphology. However, smaller nonpyramidal cells also expressed NTR1. These cells were identified as interneurons on the basis of colocalization with calcium-binding proteins (Fig. 3). The majority of PV- and CB-containing interneurons expressed NTR1-like immunoreactivity $(86 \pm 2$ and $74 \pm 4 \%$, respectively), whereas expression of NTR1-like immunoreactivity was observed in a minority $(41 \pm 3 \%)$ of CR-containing interneurons.

\section{Effect of neurotensin on extracellular amino acid transmitter levels in the PFC}

Intracortical administration of neurotensin increased extracellular GABA levels in a concentration-dependent manner. Administration of $100 \mathrm{~nm}$ neurotensin did not significantly increase extracellular GABA levels, although a trend toward an increase was noted, whereas $1 \mu \mathrm{M}$ neurotensin significantly increased extracellular GABA levels (Fig. 4). Pretreatment with $500 \mathrm{~nm}$ SR48692 through the dialysis probe completely blocked the NTevoked increase in extracellular GABA levels (Fig. 4). Local administration of either $100 \mathrm{nM}$ SR48692 $(n=3)$ or $500 \mathrm{nM}$ SR48692 $(n=5)$ did not change extracellular GABA levels when compared with vehicle (see Fig. 7). Two-way ANOVA (treatment $X$ time) with repeated measures on the time factor revealed a significant time $\times$ treatment interaction $\left(F_{(5,30)}=2.429 ; p \leq\right.$ 0.001 ) as well as significant time and treatment effects. Similarly, perfusion with the sodium channel blocker TTX blocked NTevoked increases in GABA levels (Fig. 5). Despite the NT-evoked increase in extracellular GABA levels, neurotensin did not alter extracellular glutamate levels in the cortex (Fig. 6).

Intracortical quinpirole administration caused a sharp increase in extracellular GABA levels (Fig. 7). The effect of the $\mathrm{D}_{2}$ agonist was temporally specific, being restricted to a single fraction, with GABA levels rapidly returning to baseline.

The ability of quinpirole to evoke an increase in extracellular GABA levels was completely blocked by intracortical delivery of the NTR1 antagonist SR48692 in the fraction before, during, and after administration of quinpirole (Fig. 7). ANOVA revealed a significant time $\times$ treatment interaction $\left(F_{(4,55)}=6.78 ; p \leq\right.$ $0.001)$ as well as main effects of time and treatment. Subsequent post hoc analyses revealed that quinpirole-treated animals had significantly higher GABA levels than all other treatment groups in the first fraction after quinpirole challenge. The effects of SR48692 on $\mathrm{D}_{2}$-elicited increases in extracellular GABA were not attributable to any direct effects of the NTR1 antagonist on dopamine receptors, because SR48692 did not display any significant affinity $\left(K_{\mathrm{i}}>10,000 \mathrm{~nm}\right)$ for dopamine $\mathrm{D}_{1}, \mathrm{D}_{2}, \mathrm{D}_{3}, \mathrm{D}_{4}$, or $\mathrm{D}_{5}$ receptors. 


\section{Discussion}

Neurotensin increases GABA release in the PFC, as reflected by an impulsedependent increase in extracellular GABA levels. Consistent with the localization of NTR1 to many PFC interneurons, pretreatment with an NTR1 antagonist blocked neurotensin-evoked increases in extracellular GABA levels in the PFC. Interestingly, the ability of a dopamine $\mathrm{D}_{2}$ agonist to activate GABAergic interneurons was also blocked by SR48692 pretreatment, suggesting that $\mathrm{D}_{2}$ agonist modulation of GABA neurons in the PFC may involve release of neurotensin from cortical axons that contain both neurotensin and dopamine.

\section{Expression of NTR1 on \\ GABA interneurons}

Autoradiographic and in situ hybridization studies have concluded that PFC neurons express NTR1 (Nicot et al., 1994; Alexander and Leeman, 1998), but the phenotype of NTR1-positive neurons has not been determined (Boudin et al., 1996). We found that pyramidal cells are the major cortical cell type in which NTR1 is expressed but that many interneurons defined on the basis of calcium-binding protein expression also displayed NTR1 immunoreactivity. Almost all cells in the rat PFC that express PV, CR, or CB are interneurons (DeFelipe, 1997; Gabbott et al., 1997; Gonchar and Burkhalter, 1997). Although NTR1 was expressed to varying degrees by all types of interneurons, it was most often localized to PV cells.

Ultrastructural studies indicate that dopamine axons in the PFC form synapses with interneurons (Smiley and GoldmanRakic, 1993; Sesack et al., 1995b), particularly PV-containing cells (Sesack et al., 1998). The finding that PV-containing interneurons are the major target of dopamine/neurotensin axons is consistent with our finding that NTR1 is mainly expressed by PV interneurons, although we also found that CB- and some CR-li cells express NTR1. Because dopamine axons do not synapse onto cortical CR neurons (Sesack et al., 1995a), the localization of NTR1 to CR neurons suggests that neurotensin effects on CR cells may occur by volume transmission.

\section{Local administration of neurotensin increases extracellular GABA levels}

Neurotensin dose-dependently increased extracellular GABA levels in the PFC. This is consistent with the finding of Audinat et al. (1989) that neurotensin enhances GABA-mediated IPSPs in rat PFC pyramidal cells in vitro. Because we administered neurotensin directly into the PFC and found that most interneurons express NTR1, the neurotensin-evoked increase in extracellular GABA probably reflects direct activation of GABAergic interneurons by the peptide. However, we cannot exclude the possibility that other (subcortical) sources of GABA may also contribute to neurotensin-evoked changes in GABA levels.

The neurotensin-elicited increase in extracellular GABA levels in the PFC is consistent with reports indicating that neurotensin increases extracellular GABA levels in subcortical structures, including the striatum (Tanganelli et al., 1994; Ferraro et al., 1997, 1998), globus pallidus (Ferraro et al., 1997), and hippocampus (Rakovska et al., 1998). We found that neurotensin evoked a significant increase in extracellular GABA levels, which was com-

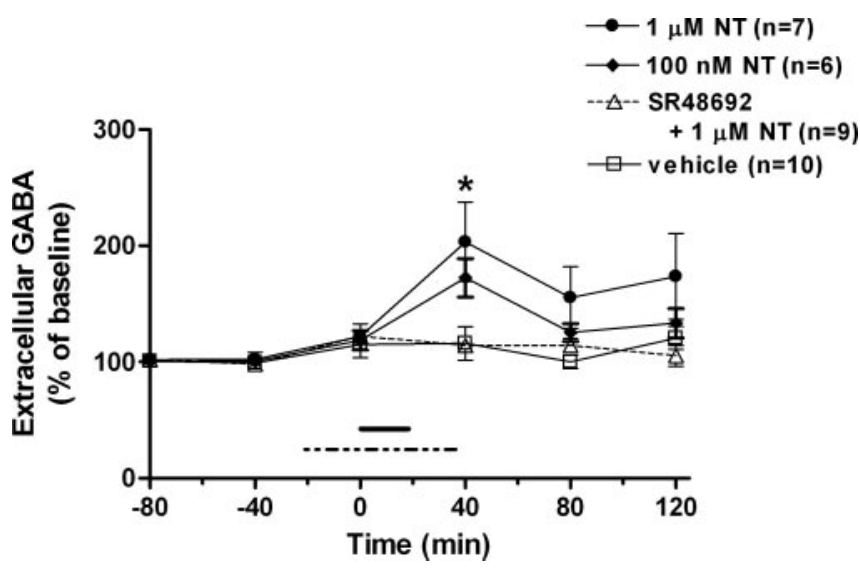

Figure 4. Effect of neurotensin on extracellular GABA levels in the PFC. Data are presented as the mean \pm SEM percentage change from baseline. Local infusion of neurotensin (solid bars) caused a dose-related increase in extracellular GABA levels. Local infusion of SR48692 (500 nm; dashed bar) blocked the increase in extracellular GABA evoked by neurotensin. ${ }^{*} p \leq 0.01$ for 1 $\mu \mathrm{m}$ NT-treated animals compared with vehicle- and SR48692-treated animals.

parable in magnitude to neurotensin-induced changes in GABA levels in subcortical sites. The small magnitude of neurotensinevoked GABA increases probably reflects metabolism of exogenously administered neurotensin by metalloendopeptidases (Woulfe et al., 1992), which play an important role in regulating neurotensin activity in vivo (Vincent et al., 1997a,b; O'Connor, 2001).

The neurotensin-induced increase in cortical extracellular GABA levels was blocked by pretreatment with SR48692. This observation is consistent with our previous data indicating that SR48692 blocked the ability of the NTR1 agonist PD149163 to increase Fos expression in PFC GABA interneurons (Petrie et al., 2004). Together, these data suggest a specific role for NTR1 in regulating GABA interneuron activity. Although all three neurotensin receptor subtypes are expressed in the cortex (Alexander and Leeman, 1998; Sarret et al., 2003a,b), neurotensin acts as an NTR2 antagonist in heterologous expression systems (Vita et al., 1998; Yamada et al., 1998), and NTR3 is primarily localized to intracellular compartments (Mazella et al., 1998; Sarret et al., 2003a), suggesting that NT-evoked increases in extracellular 


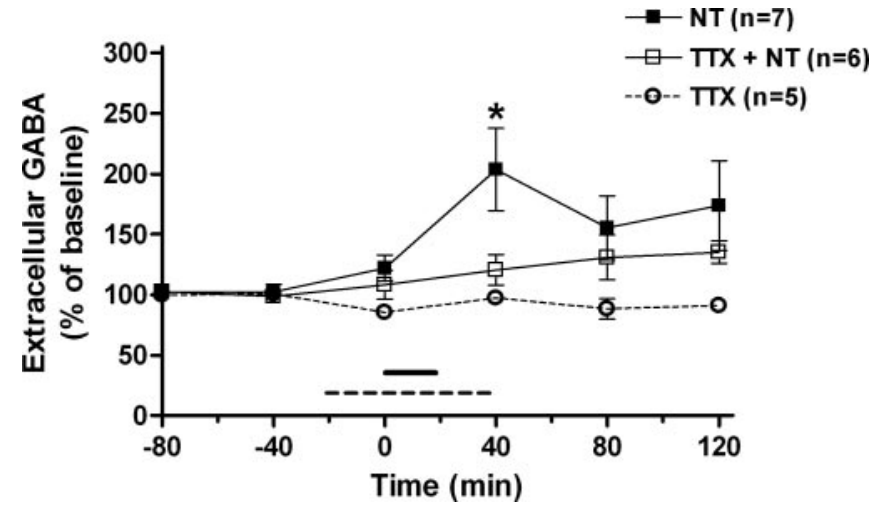

Figure 5. Effect of the sodium channel blocker tetrodoxin on NT-elicited increases in extracellular GABA levels in the PFC. Intracortical TTX ( $1 \mu \mathrm{m}$ through the dialysis probe; dashed line) completely blocked the increase in extracellular GABA elicited by $1 \mu \mathrm{m} \mathrm{NT}$ (solid line). ${ }^{*} p \leq 0.05$ for NT-treated animals compared with all other treatment groups. Error bars represent SEM.

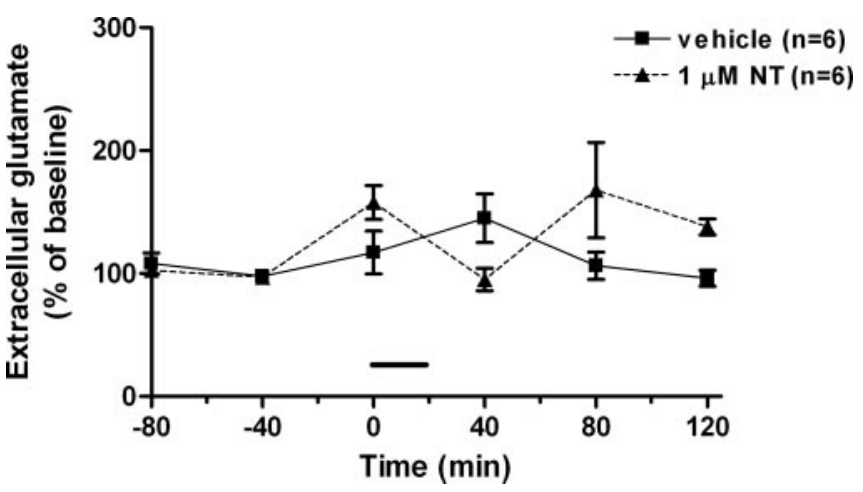

Figure 6. Effect of neurotensin on extracellular glutamate levels in the PFC. Local infusion of neurotensin (solid line) did not significantly change extracellular glutamate levels compared with vehicle-treated animals. Error bars represent SEM.

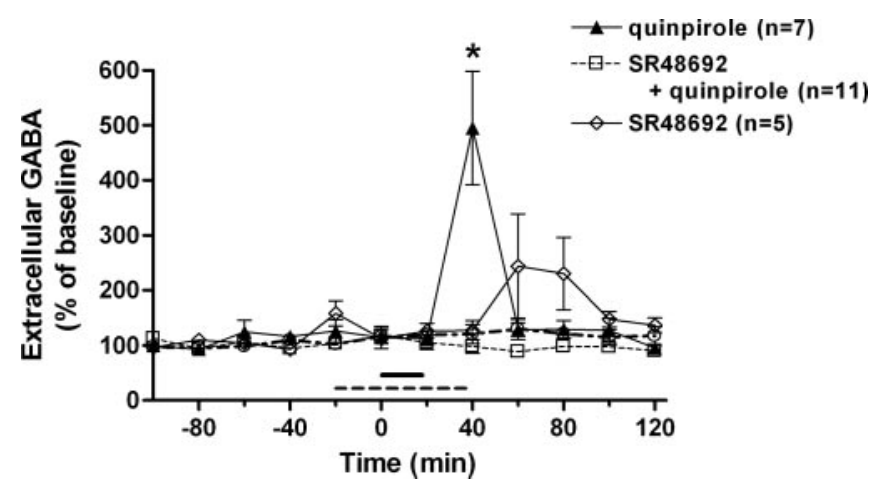

Figure 7. Effect of quinpirole on extracellular GABA levels in the PFC. Data are presented as the mean \pm SEM percentage change from baseline. Local infusion of quinpirole (100 $\mu \mathrm{M}$ through the dialysis probe; solid bar) significantly increased extracellular GABA levels compared with vehicle-treated animals and to baseline values. Local infusion of SR48692 (500 nm; dashed bar) completely blocked quinpirole-elicited increases in extracellular GABA but had no significant effect when administered alone. ${ }^{*} p \leq 0.01$ for quinpirole-treated animals compared with all other treatment groups.

GABA levels are mediated by NTR1 but not NTR2 or NTR3 receptors.

NTR1 is localized to pyramidal cells as well as GABAergic interneurons. The axon collaterals of pyramidal cells synapse onto and functionally regulate interneurons (DeFelipe and Farinas, 1992; Staiger et al., 1996; Buhl et al., 1997), and recent reports suggest that glutamate agonists increase extracellular GABA in the rat PFC (Del Arco and Mora, 2000, 2002). It is therefore possible that neurotensin-induced increases in extracellular GABA levels are indirect, initiated by activation of NTR1 on pyramidal cells. However, we failed to detect a consistent increase in extracellular glutamate levels after local neurotensin administration, suggesting that neurotensin-evoked increases in extracellular GABA are not secondary to local changes in glutamate release. Because dialysis lacks the temporal resolution to define transient changes in glutamate, which is quickly cleared by glutamate transporters, we cannot rule out the possibility that a brief increase in glutamate release drives GABA neurons.

\section{Dopamine $\mathrm{D}_{2}$ agonist-evoked increases in extracellular GABA levels}

We previously reported that systemic and local administration of $\mathrm{D}_{2}$ - but not $\mathrm{D}_{1}$-like dopamine agonists increases extracellular GABA levels in the PFC (Grobin and Deutch, 1998). These data were puzzling because $D_{2}$ receptors are typically coupled to inhibitory signal transduction pathways (Missale et al., 1998). Dopamine $\mathrm{D}_{2}$ receptors are expressed by interneurons and pyramidal cells in the PFC and are present on dopamine axons, where they function as release-modulating autoreceptors (Wolf and Roth, 1987). In a series of studies, Bean et al. (1990) and Bean and Roth (1991) demonstrated that activation of $\mathrm{D}_{2}$ autoreceptors in the PFC decreases dopamine release but increases release of the colocalized peptide transmitter neurotensin.

Thus, $\mathrm{D}_{2}$ agonists may alter the activity of PFC neurons that are postsynaptic to dopaminergic axons by promoting neurotensin release. Activation of NTR1 increases intracellular calcium (Hermans et al., 1994), stimulates cyclic nucleotide production (Yamada et al., 1993; Slusher et al., 1994), and promotes phospholipase C activity (Hermans et al., 1992; Watson et al., 1992), consistent with neurotensin-elicited excitatory effects occurring through activation of NTR1. These observations suggest that quinpirole may increase extracellular GABA levels in the PFC indirectly, by promoting neurotensin release from colocalized neurotensin-dopamine axons. The released neurotensin would in turn target NTR1 on GABAergic cells to activate interneurons.

Consistent with our hypothesis that $\mathrm{D}_{2}$ agonist-evoked increases in extracellular GABA levels in the PFC are secondary to release of neurotensin, we found that SR48692 pretreatment completely blocked quinpirole-evoked increases in PFC GABA levels. However, the NTR1 antagonist alone did not alter GABA levels, suggesting that neurotensin does not play a significant role in regulating basal GABA release. This agrees well with observations that peptide transmitters in colocalized peptidemonoamine neurons are released during high-frequency firing rates or under burst firing conditions, but under basal conditions, peptide release is low.

The SR48692-mediated disruption of $\mathrm{D}_{2}$-elicited increases in GABA levels is likely attributable to actions at NTR1. The affinity of SR48692 for NTR1 ( 3 nM) is two orders of magnitude greater than that observed at NTR2 (Labbe-Jullie et al., 1995; Mazella et al., 1996). Consistent with previous data, we estimate that the concentration of SR48692 delivered across the dialysis membrane is $<20 \%$ of the $500 \mathrm{~nm} \mathrm{SR} 48692$ infused through the probe, and thus the effective concentration of SR48692 is consistent with actions at NTR1. As noted previously, the efficient metabolism of exogenous neurotensin by metalloendopeptidases probably accounts for the difference in magnitude between neurotensin- and quinpirole-evoked changes in GABA levels. Moreover, synaptically released neurotensin is more likely to act on postsynaptic 
(GABAergic) targets than exogenous peptide administered by reverse dialysis into the extracellular space.

\section{Implications}

Neurotensin has been suggested to act as an endogenous antipsychotic drug (APD) (Nemeroff, 1980) based on the similarities of the behavioral effects observed in animals treated with APDs or injected centrally with neurotensin (Kinkead et al., 1999). Several studies have reported that CSF neurotensin levels are reduced in schizophrenic patients, especially those with prominent negative symptoms (Widerlov et al., 1982; Garver et al., 1991), and normalize after APD treatment (Breslin et al., 1994).

Our studies were performed in the rat. The laminar distributions of dopamine- and neurotensin-li axons in the PFC of primate species differ from those seen in the rat (Gaspar et al., 1990), suggesting that neurotensin may not be colocalized with dopamine in humans. However, it is possible that neurotensin may not be detectable in cortical dopamine axons under basal conditions but may be rapidly induced and become apparent after appropriate challenges, as is the case in striatal neurons (Merchant et al., 1991; Deutch and Zahm, 1992). Furthermore, tyrosine hydroxylase and neurotensin mRNAs are colocalized in some human ventral tegmental area neurons, although the projection target(s) of these neurons remains unknown (Bean et al., 1992). Even if neurotensin and dopamine are not colocalized in the primate $\mathrm{PFC}$, activation of $\mathrm{D}_{2}$ heteroreceptors on neurotensin axons may promote neurotensin release.

Dysfunction of the prefrontal cortex has been suggested to underlie the cognitive deficits and negative symptoms of schizophrenia (Weinberger et al., 1986; Goldman-Rakic and Selemon, 1997; Volk and Lewis, 2002). These features of the illness are relatively resistant to treatment with typical APDs, which are potent $\mathrm{D}_{2}$ receptor antagonists. If increases in cortical neurotensin contribute to the reduction of negative symptoms and cognitive deficits in schizophrenia, and neurotensin release is promoted by $D_{2}$ receptor agonists, this may explain why typical APDs do not treat primary negative symptoms and cognitive deficits effectively. Our data suggest that agents that increase cortical neurotensin may be a useful adjunctive treatment for schizophrenia.

\section{References}

Akbarian S, Kim JJ, Potkin SG, Hagman JO, Tafazzoli A, Bunney Jr WE, Jones EG (1995) Gene expression for glutamic acid decarboxylase is reduced without loss of neurons in prefrontal cortex of schizophrenics. Arch Gen Psychiatry 52: 258-266.

Alexander MJ, Leeman SE (1998) Widespread expression in adult rat forebrain of mRNA encoding high-affinity neurotensin receptor. J Comp Neurol 402:475-500.

Audinat E, Hermel JM, Crepel F (1989) Neurotensin-induced excitation of neurons of the rat's frontal cortex studied intracellularly in vitro. Exp Brain Res 78:358-368.

Bean AJ, Roth RH (1991) Extracellular dopamine and neurotensin in rat prefrontal cortex in vivo: effects of median forebrain bundle stimulation frequency, stimulation pattern, and dopamine autoreceptors. J Neurosci 11:2694-2702.

Bean AJ, During MJ, Roth RH (1990) Effects of dopamine autoreceptor stimulation on the release of colocalized transmitters: in vivo release of dopamine and neurotensin from rat prefrontal cortex. Neurosci Lett 108:143-148.

Bean AJ, Dagerlind A, Hokfelt T, Dobner PR (1992) Cloning of human neurotensin/neuromedin $\mathrm{N}$ genomic sequences and expression in the ventral mesencephalon of schizophrenics and age/sex matched controls. Neuroscience 50:259-268.

Beasley CL, Reynolds GP (1997) Parvalbumin-immunoreactive neurons are reduced in the prefrontal cortex of schizophrenics. Schizophr Res 24:349-355.
Benes FM, Vincent SL, Marie A, Khan Y (1996) Up-regulation of GABAA receptor binding on neurons of the prefrontal cortex in schizophrenic subjects. Neuroscience 75:1021-1031.

Boudin H, Gruaz-Guyon A, Faure MP, Forgez P, Lhiaubet AM, Dennis M, Beaudet A, Rostene W, Pelaprat D (1995) Immunological recognition of different forms of the neurotensin receptor in rat brain: immunohistochemical study using an antipeptide antibody against the cloned high affinity receptor. Biochem J 305:277-283.

Boudin H, Pelaprat D, Rostene W, Beaudet A (1996) Cellular distribution of neurotensin receptors in rat brain: immunohistochemical study using an antipeptide antibody against the cloned high affinity receptor. J Comp Neurol 373:76-89.

Breslin NA, Suddath RL, Bissette G, Nemeroff CB, Lowrimore P, Weinberger DR (1994) CSF concentrations of neurotensin in schizophrenia: an investigation of clinical and biochemical correlates. Schizophr Res 12:35-41.

Buhl EH, Tamas G, Szilagyi T, Stricker C, Paulsen O, Somogyi P (1997) Effect, number and location of synapses made by single pyramidal cells onto aspiny interneurones of cat visual cortex. J Physiol (Lond) 500:689-713.

Carraway RE, Mitra SP, Honeyman TW (1993) Effects of GTP analogs and metal ions on the binding of neurotensin to porcine brain membranes. Peptides 14:37-45.

Carraway RE, Gui X, Cochrane DE (2003) Ca2 + channel blockers enhance neurotensin (NT) binding and inhibit NT-induced inositol phosphate formation in prostate cancer PC3 cells. J Pharmacol Exp Ther 307:640-650.

Daviss SR, Lewis DA (1995) Local circuit neurons of the prefrontal cortex in schizophrenia: selective increase in the density of calbindinimmunoreactive neurons. Psychiatry Res 59:81-96.

DeFelipe J (1997) Types of neurons, synaptic connections and chemical characteristics of cells immunoreactive for calbindin-d28k, parvalbumin and calretinin in the neocortex. J Chem Neuroanat 14:1-19.

DeFelipe J, Farinas I (1992) The pyramidal neuron of the cerebral cortex: morphological and chemical characteristics of the synaptic inputs. Prog Neurobiol 39:563-607.

Del Arco A, Mora F (2000) Endogenous dopamine potentiates the effects of glutamate on extracellular GABA in the prefrontal cortex of the freely moving rat. Brain Res Bull 53:339-345.

Del Arco A, Mora F (2002) NMDA and AMPA/kainate glutamatergic agonists increase the extracellular concentrations of GABA in the prefrontal cortex of the freely moving rat: modulation by endogenous dopamine. Brain Res Bull 57:623-630.

Deutch AY, Zahm DS (1992) The current status of neurotensin-dopamine interactions. Issues and speculations. Ann NY Acad Sci 668:232-252.

Fadel J, Deutch AY (2002) Anatomical substrates of orexin-dopamine interactions: lateral hypothalamic projections to the ventral tegmental area. Neuroscience 111:379-387.

Febvret A, Berger B, Gaspar P, Verney C (1991) Further indication that distinct dopaminergic subsets project to the rat cerebral cortex: lack of colocalization with neurotensin in the superficial dopaminergic fields of the anterior cingulate, motor, retrosplenial and visual cortices. Brain Res 547:37-52.

Ferraro L, O'Connor WT, Antonelli T, Fuxe K, Tanganelli S (1997) Differential effects of intrastriatal neurotensin(1-13) and neurotensin(8-13) on striatal dopamine and pallidal GABA release. A dual-probe microdialysis study in the awake rat. Eur J Neurosci 9:1838-1846.

Ferraro L, Antonelli T, O'Connor WT, Fuxe K, Soubrie P, Tanganelli S (1998) The striatal neurotensin receptor modulates striatal and pallidal glutamate and GABA release: functional evidence for a pallidal glutamateGABA interaction via the pallidal-subthalamic nucleus loop. J Neurosci 18:6977-6989.

Gabbott PL, Dickie BG, Vaid RR, Headlam AJ, Bacon SJ (1997) Localcircuit neurones in the medial prefrontal cortex (areas 25, 32 and 24b) in the rat: morphology and quantitative distribution. J Comp Neurol 377:465-499.

Garver DL, Bissette G, Yao JK, Nemeroff CB (1991) Relation of CSF neurotensin concentrations to symptoms and drug response of psychotic patients. Am J Psychiatry 148:484-488.

Gaspar P, Berger B, Febvret A (1990) Neurotensin innervation of the human cerebral cortex: lack of colocalization with catecholamines. Brain Res 530:181-195. 
Goldman-Rakic PS, Selemon LD (1997) Functional and anatomical aspects of prefrontal pathology in schizophrenia. Schizophr Bull 23:437-458.

Gonchar Y, Burkhalter A (1997) Three distinct families of GABAergic neurons in rat visual cortex. Cereb Cortex 7:347-358.

Grobin AC, Deutch AY (1998) Dopaminergic regulation of extracellular gamma-aminobutyric acid levels in the prefrontal cortex of the rat. J Pharmacol Exp Ther 285:350-357.

Hashimoto T, Volk DW, Eggan SM, Mirnics K, Pierri JN, Sun Z, Sampson AR, Lewis DA (2003) Gene expression deficits in a subclass of GABA neurons in the prefrontal cortex of subjects with schizophrenia. J Neurosci 23:6315-6326.

Hermans E, Maloteaux JM, Octave JN (1992) Phospholipase Cactivation by neurotensin and neuromedin $\mathrm{N}$ in Chinese hamster ovary cells expressing the rat neurotensin receptor. Brain Res Mol Brain Res 15:332-338.

Hermans E, Gailly P, Octave JN, Maloteaux JM (1994) Rapid desensitization of agonist-induced calcium mobilization in transfected PC12 cells expressing the rat neurotensin receptor. Biochem Biophys Res Commun 198:400-407.

Hokfelt T, Everitt BJ, Theodorsson-Norheim E, Goldstein M (1984) Occurrence of neurotensinlike immunoreactivity in subpopulations of hypothalamic, mesencephalic, and medullary catecholamine neurons. J Comp Neurol 222:543-559.

Kawaguchi Y, Kubota Y (1993) Correlation of physiological subgroupings of nonpyramidal cells with parvalbumin- and calbindinD28kimmunoreactive neurons in layer $\mathrm{V}$ of rat frontal cortex. J Neurophysiol 70:387-396.

Kinkead B, Binder EB, Nemeroff CB (1999) Does neurotensin mediate the effects of antipsychotic drugs? Biol Psychiatry 46:340-351.

Labbe-Jullie C, Botto JM, Mas MV, Chabry J, Mazella J, Vincent JP, Gully D, Maffrand JP, Kitabgi P (1995) [3H]SR 48692, the first nonpeptide neurotensin antagonist radioligand: characterization of binding properties and evidence for distinct agonist and antagonist binding domains on the rat neurotensin receptor. Mol Pharmacol 47:1050-1056.

Mazella J, Botto JM, Guillemare E, Coppola T, Sarret P, Vincent JP (1996) Structure, functional expression, and cerebral localization of the levocabastine-sensitive neurotensin/neuromedin $\mathrm{N}$ receptor from mouse brain. J Neurosci 16:5613-5620.

Mazella J, Zsurger N, Navarro V, Chabry J, Kaghad M, Caput D, Ferrara P, Vita N, Gully D, Maffrand JP, Vincent JP (1998) The 100-kDa neurotensin receptor is gp95/sortilin, a non-G-protein-coupled receptor. J Biol Chem 273:26273-26276.

Mendez M, Souaze F, Nagano M, Kelley PA, Rostene W, Forgez P (1997) High affinity neurotensin receptor mRNA distribution in rat brain and peripheral tissues. Analysis by quantitative RT-PCR. J Mol Neurosci 9:93-102.

Merchant KM, Miller MA, Ashleigh EA, Dorsa DM (1991) Haloperidol rapidly increases the number of neurotensin mRNA-expressing neurons in neostriatum of the rat brain. Brain Res 540:311-314.

Missale C, Nash SR, Robinson SW, Jaber M, Caron MG (1998) Dopamine receptors: from structure to function. Physiol Rev 78:189-225.

Nemeroff CB (1980) Neurotensin: perchance an endogenous neuroleptic? Biol Psychiatry 15:283-302.

Nicot A, Rostene W, Berod A (1994) Neurotensin receptor expression in the rat forebrain and midbrain: a combined analysis by in situ hybridization and receptor autoradiography. J Comp Neurol 341:407-419.

O'Connor WT (2001) Functional neuroanatomy of the ventral striopallidal GABA pathway. New sites of intervention in the treatment of schizophrenia. J Neurosci Methods 109:31-39.

Ohnuma T, Augood SJ, Arai H, McKenna PJ, Emson PC (1999) Measurement of GABAergic parameters in the prefrontal cortex in schizophrenia: focus on GABA content, GABA(A) receptor alpha-1 subunit messenger RNA and human GABA transporter-1 (HGAT-1) messenger RNA expression. Neuroscience 93:441-448.

Paxinos G, Watson C (1986) The rat brain in stereotaxic coordinates. San Diego: Academic.

Petrie KA, Bubser M, Casey CD, Davis MD, Roth BL, Deutch AY (2004) The neurotensin agonist PD149163 increases Fos expression in the prefrontal cortex of the rat. Neuropychopharmacology 29:1878-1888.

Pierri JN, Chaudry AS, Woo TU, Lewis DA (1999) Alterations in chandelier neuron axon terminals in the prefrontal cortex of schizophrenic subjects. Am J Psychiatry 156:1709-1719.

Rakovska A, Giovannini MG, Della Corte L, Kalfin R, Bianchi L, Pepeu G
(1998) Neurotensin modulation of acetylcholine and GABA release from the rat hippocampus: an in vivo microdialysis study. Neurochem Int 33:335-340.

Reynolds GP, Beasley CL (2001) GABAergic neuronal subtypes in the human frontal cortex-development and deficits in schizophrenia. J Chem Neuroanat 2001 22:95-100.

Reynolds GP, Beasley CL, Zhang ZJ (2002) Understanding the neurotransmitter pathology of schizophrenia: selective deficits of subtypes of cortical GABAergic neurons. J Neural Transm 109:881-889.

Sarret P, Krzywkowski P, Segal L, Nielsen MS, Petersen CM, Mazella J, Stroh T, Beaudet A (2003a) Distribution of nts3 receptor/sortilin mRNA and protein in the rat central nervous system. J Comp Neurol 461:483-505.

Sarret P, Perron A, Stroh T, Beaudet A (2003b) Immunohistochemical distribution of nts2 neurotensin receptors in the rat central nervous system. J Comp Neurol 461:520-538.

Seroogy KB, Mehta A, Fallon JH (1987) Neurotensin and cholecystokinin coexistence within neurons of the ventral mesencephalon: projections to forebrain. Exp Brain Res 68:277-289.

Sesack SR, Bressler CN, Lewis DA (1995a) Ultrastructural associations between dopamine terminals and local circuit neurons in the monkey prefrontal cortex: a study of calretinin-immunoreactive cells. Neurosci Lett 200:9-12.

Sesack SR, Snyder CL, Lewis DA (1995b) Axon terminals immunolabeled for dopamine or tyrosine hydroxylase synapse on GABA-immunoreactive dendrites in rat and monkey cortex. J Comp Neurol 363:264-280.

Sesack SR, Hawrylak VA, Melchitzky DS, Lewis DA (1998) Dopamine innervation of a subclass of local circuit neurons in monkey prefrontal cortex: ultrastructural analysis of tyrosine hydroxylase and parvalbumin immunoreactive structures. Cereb Cortex 8:614-622.

Shapiro DA, Renock S, Arrington E, Chiodo LA, Liu LX, Sibley DR, Roth BL, Mailman R (2003) Aripiprazole, a novel atypical antipsychotic drug with a unique and robust pharmacology. Neuropsychopharmacology 28:1400-1411.

Slusher BS, Zacco AE, Maslanski JA, Norris TE, McLane MW, Moore WC, Rogers NE, Ignarro LJ (1994) The cloned neurotensin receptor mediates cyclic GMP formation when coexpressed with nitric oxide synthase cDNA. Mol Pharmacol 46:115-121.

Smiley JF, Goldman-Rakic PS (1993) Heterogeneous targets of dopamine synapses in monkey prefrontal cortex demonstrated by serial section electron microscopy: a laminar analysis using the silver-enhanced diaminobenzidine sulfide (SEDS) immunolabeling technique. Cereb Cortex 3:223-238.

Staiger JF, Zilles K, Freund TF (1996) Recurrent axon collaterals of corticothalamic projection neurons in rat primary somatosensory cortex contribute to excitatory and inhibitory feedback-loops. Anat Embryol (Berl) 194:533-543.

Studler JM, Kitabgi P, Tramu G, Herve D, Glowinski J, Tassin JP (1988) Extensive co-localization of neurotensin with dopamine in rat mesocortico-frontal dopaminergic neurons. Neuropeptides 11:95-100.

Tanganelli S, O'Connor WT, Ferraro L, Bianchi C, Beani L, Ungerstedt U, Fuxe K (1994) Facilitation of GABA release by neurotensin is associated with a reduction of dopamine release in rat nucleus accumbens. Neuroscience 60:649-657.

Vincent B, Jiracek J, Noble F, Loog M, Roques B, Dive V, Vincent JP, Checler F (1997a) Effect of a novel selective and potent phosphinic peptide inhibitor of endopeptidase 3.4.24.16 on neurotensin-induced analgesia and neuronal inactivation. Br J Pharmacol 121:705-710.

Vincent B, Jiracek J, Noble F, Loog M, Roques B, Dive V, Vincent JP, Checler F (1997b) Contribution of endopeptidase 3.4.24.15 to central neurotensin inactivation. Eur J Pharmacol 334:49-53.

Vita N, Oury-Donat F, Chalon P, Guillemot M, Kaghad M, Bachy A, Thurneyssen O, Garcia S, Poinot-Chazel C, Casellas P, Keane P, Le Fur G, Maffrand JP, Soubrie P, Caput D, Ferrara P (1998) Neurotensin is an antagonist of the human neurotensin nt2 receptor expressed in Chinese hamster ovary cells. Eur J Pharmacol 360:265-272.

Volk D, Austin M, Pierri J, Sampson A, Lewis D (2001) GABA transporter-1 mRNA in the prefrontal cortex in schizophrenia: decreased expression in a subset of neurons. Am J Psychiatry 158:256-265.

Volk DW, Lewis DA (2002) Impaired prefrontal inhibition in schizophrenia: relevance for cognitive dysfunction. Physiol Behav 77:501-505.

Volk DW, Austin MC, Pierri JN, Sampson AR, Lewis DA (2000) Decreased glutamic acid decarboxylase67 messenger RNA expression in a subset of 
prefrontal cortical gamma-aminobutyric acid neurons in subjects with schizophrenia. Arch Gen Psychiatry 57:237-245.

Watson MA, Yamada M, Cusack B, Veverka K, Bolden-Watson C, Richelson E (1992) The rat neurotensin receptor expressed in Chinese hamster ovary cells mediates the release of inositol phosphates. J Neurochem 59:1967-1970.

Weinberger DR, Berman KF, Zec RF (1986) Physiologic dysfunction of dorsolateral prefrontal cortex in schizophrenia. I. Regional cerebral blood flow evidence. Arch Gen Psychiatry 43:114-124.

Widerlov E, Lindstrom LH, Besev G, Manberg PJ, Nemeroff CB, Breese GR, Kizer JS, Prange Jr AJ (1982) Subnormal CSF levels of neurotensin in a subgroup of schizophrenic patients: normalization after neuroleptic treatment. Am J Psychiatry 139:1122-1126.
Wolf ME, Roth RH (1987) Dopamine neurons projecting to the medial prefrontal cortex possess release-modulating autoreceptors. Neuropharmacology 26:1053-1059.

Woulfe J, Checler F, Beaudet A (1992) Light and electron microscopic localization of the neutral metalloendopeptidase EC 3.4.24.16 in the mesencephalon of the rat. Eur J Neurosci 4:1309-1319.

Yamada M, Watson MA, Richelson E (1993) Neurotensin stimulates cyclic AMP formation in CHO-rNTR-10 cells expressing the cloned rat neurotensin receptor. Eur J Pharmacol 244:99-101.

Yamada M, Lombet A, Forgez P, Rostene W (1998) Distinct functional characteristics of levocabastine sensitive rat neurotensin $n t 2$ receptor expressed in chinese hamster ovary cells. Life Sci 62:375-380. 